\title{
Mediastinal lymphoma presenting with asymmetrical chest wall
}

\author{
Jeyasakthy Saniasiaya
}

Otorhinolaryngology, University of Malaya, Kuala Lumpur, Negeri Sembilan, Malaysia

\section{Correspondence to} Dr Jeyasakthy Saniasiaya; shakthy_18@yahoo.com

Accepted 10 December 2021
Check for updates

(c) BMJ Publishing Group Limited 2022. No commercial re-use. See rights and permissions. Published by BMJ.

To cite: Saniasiaya J. BMJ Case Rep 2022:15:e246953. doi:10.1136/bcr-2021246953

\section{DESCRIPTION}

A previously healthy 29 -year-old man presented with an anterior chest wall asymmetry, which according to the patient, developed insidiously and persisted with no obstructive symptoms. There was additionally significant unintentional weight loss of $5 \mathrm{~kg}$ over the past 6 months. On further questioning, the patient mentioned that a blood test performed for routine medical check-up revealed iron-deficiency anaemia features, and he was given haematinics which he defaulted. No inciting trauma, fever, drug allergy or travel history was unveiled. Additionally, no signs and symptoms of anaemia were demonstrated. On examination, the patient appeared comfortable under room air, with no pallor. Non-erythematous, generalised facial puffiness was noted with no palpable neck swelling. The anterior chest wall appeared asymmetric, which was prominent over the right anterior chest wall. Pemberton test result was negative (figure 1). Besides features of hypochromic microcytic anaemia, other routine blood investigations along with electrolytes were within the normal range. A chest radiograph revealed widening of the mediastinum with no abnormal lucency (figure 2).

The patient subsequently underwent a CT of the thorax, which revealed an enhancing anterior mediastinal mass extending from sternal manubrium to the xiphoid process measuring $9.0 \times 12 \times 14 \mathrm{~cm}$ (figure 3). A histopathological examination of a CT-guided biopsy revealed neoplastic lymphoid cells, which appeared to be mononuclear Hodgkin's and multinucleated Reed-Sternberg cells, and prominent nucleoli with frequent mitotic figures. Immunohistochemistry staining is positive for CD79a, PAX5 and CD30, which was consistent with classical Hodgkin's lymphoma (HL). The patient was referred to the haematology unit, and chemotherapy was started. The patient responded positively to prompt chemotherapy.

Primary mediastinal malignancy is a rare entity with vague clinical presentations. Lymphoma stands as the most common malignancy of the mediastinum, notably HL. HL is a haematological malignancy that shows bimodal distribution of age, exhibiting peaks at adolescence and after 50 years. ${ }^{1}$ Early intrathoracic involvement has been documented in more than $80 \%$ of cases especially involving the anterior mediastinal as well as the paratracheal nodes. ${ }^{2}$ Nearly $50 \%$ of patients with primary mediastinal HL remains oblivious on presentation as it is oftentimes discovered incidentally. However, patients may complain of vague symptoms such as chest pain, fatigue, dyspnoea or cough. B-symptoms (fever, drenching night sweats and

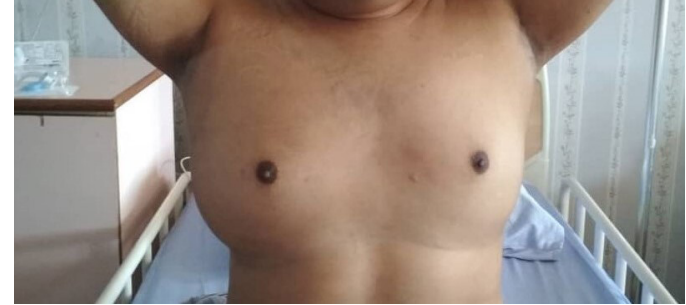

Figure 1 Asymetrical chest wall with negative Pamberton's sign.

significant weight loss) have been classically linked to HL in only $30 \%$ of patients, whereas itchiness is found nearly in $15 \%$ of patients. ${ }^{3}$ Interestingly, Pel-Ebstein fever, although linked to HL, is also non-specific. ${ }^{3}$ Superior vena cava syndrome is uncommonly seen, which can be elicited by the Pemberton's sign. ${ }^{3}$

First described by Dr Hugh Pemberton in 1946, Pemberton's sign is described by facial redness and venous engorgement on bilateral arm elevation which occurs due to clavicular movement resulting in a 'nutcracker' effect which compresses major venous structures. Pemberton's sign is reported to be a quick manoeuvre to diagnose superior vena cava syndrome from all aetiologies. ${ }^{4}$

Laboratory investigations that may favour lymphoma diagnosis include leucocytosis, absolute neutrophilia or eosinophilia, lymphopenia, which can be accompanied by microcytic hypochromic anaemia, and elevated erythrocyte sedimentation rate and lactate dehydrogenase, which correlates with advanced disease. ${ }^{3}$

A simple plain posterior-anterior radiograph may reveal a widened mediastinum as in our patient.

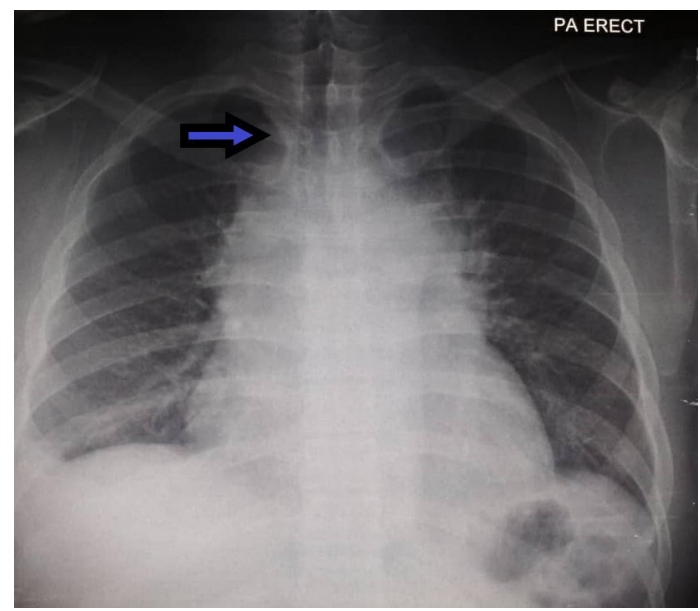

Figure 2 Chest X-ray with widening of mediastinum. 


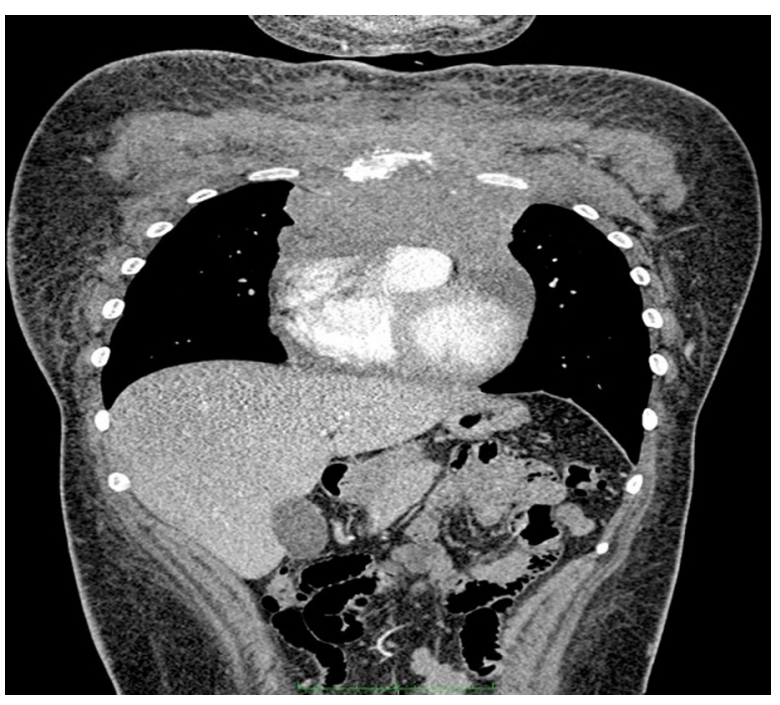

Figure 3 CT thorax revealing anterior mediastinal mass.

Additionally, primary mediastinal HL appears with a radiopaque mass with smooth or lobulated borders. A lateral view radiograph can verify the localisation of the tumour, which can be either anterior or middle mediastinal. Imaging features of anterior mediastinal mass include multiple, homogeneous soft-tissue mass, although heterogeneous features with low attenuation due to necrosis, haemorrhage or cyst formation can be seldom noted. ${ }^{5}$

Asymmetric anterior chest wall points to the diagnosis of amazia and amastia. In our patient, the presence of irondeficiency anaemia with significant weight loss accompanying asymmetric chest wall points towards a more serious pathology.

Gold standard treatment for HL remains a combination of chemotherapy and radiotherapy to the involved site, which has an overall good prognosis, especially in Stages I and II. Various chemotherapy protocols include ABVD (Adriamycin, bleomycin, vincristine and doxorubicin), Stanford V regime (doxorubicin, vinblastine, mechlorethamine, vincristine, bleomycin, prednisolone), escalated BEACOPP (bleomycin, etoposide, Adriamycin, cyclophosphamide, Oncovin, procarbazine, prednisolone) with involved-site radiotherapy (ISRT). ${ }^{6}$

\section{Learning points}

- Atypical presentation such as asymmetrical anterior chest wall ought to be investigated instantly.

- Simple investigation such as chest radiography may reveal the presence of mass or widening of the mediastinum.

- Unexplained abnormal results of routine blood investigation such as anaemia, in addition to unexplained weight loss, should be investigated thoroughly.

Contributors JS: Drafting, writing, literature review.

Funding The authors have not declared a specific grant for this research from any funding agency in the public, commercial or not-for-profit sectors.

Competing interests None declared.

Patient consent for publication Consent obtained directly from patient(s).

Provenance and peer review Not commissioned; externally peer reviewed.

Case reports provide a valuable learning resource for the scientific community and can indicate areas of interest for future research. They should not be used in isolation to guide treatment choices or public health policy.

\section{ORCID iD}

Jeyasakthy Saniasiaya http://orcid.org/0000-0003-1974-4379

\section{REFERENCES}

1 Gobbi PG, Ferreri AJM, Ponzoni M, et al. Hodgkin lymphoma. Crit Rev Oncol Hematol 2013;85:216-37.

2 Sharma A, Fidias P, Hayman LA, et al. Patterns of lymphadenopathy in thoracic malignancies. Radiographics 2004;24:419-34.

3 Piña-Oviedo S, Moran CA. Primary mediastinal classical Hodgkin lymphoma. Adv Anat Pathol 2016;23:285-309.

4 Keshvani N, Yek C, Johnson DH. Pemberton's sign in SVC syndrome from metastatic renal cell carcinoma. BMJ Case Rep 2018;2018.

5 Tang S-S, Yang Z-G, Deng W, et al. Differentiation between tuberculosis and lymphoma in mediastinal lymph nodes: evaluation with contrast-enhanced MDCT. Clin Radiol 2012:67:877-83.

6 Hoppe RT, Advani RH, Ai WZ, et al. Hodgkin lymphoma, version 2.2012 featured updates to the NCCN guidelines. J Nat/ Compr Canc Netw 2012;10:589-97.

Copyright 2021 BMJ Publishing Group. All rights reserved. For permission to reuse any of this content visit

https://www.bmj.com/company/products-services/rights-and-licensing/permissions/

BMJ Case Report Fellows may re-use this article for personal use and teaching without any further permission.

Become a Fellow of BMJ Case Reports today and you can:

- Submit as many cases as you like

- Enjoy fast sympathetic peer review and rapid publication of accepted articles

- Access all the published articles

- Re-use any of the published material for personal use and teaching without further permission

Customer Service

If you have any further queries about your subscription, please contact our customer services team on +44 (0) 2071111105 or via email at support@bmj.com.

Visit casereports.bmj.com for more articles like this and to become a Fellow 